\title{
Policy Change in Prostitution in the Netherlands: from Legalization to Strict Control
}

\author{
Joyce Outshoorn
}

Published online: 19 June 2012

(C) The Author(s) 2012. This article is published with open access at Springerlink.com

\begin{abstract}
The Netherlands legalized prostitution in 1999 and is currently debating a new bill, the 'Law regulating prostitution and suppressing abuse in the sex industry'. The legalization made a distinction between voluntary sex work, which is legal, and forced prostitution, which remains a criminal offence. In the 2000 s, evaluations showed that, while there is a reasonably working legal prostitution sector, abuse, bad working conditions and trafficking still occur. The media have played an important role in reframing the issue, and politicians have successfully set the revision of the legalization on the agenda, resulting in a new bill at the end of the decade. With this proposal and its framing of fighting human trafficking and organized crime, the Netherlands is reneging on its original progressive legalization by adopting a strict regulation of all prostitution. Sex workers will have to register with the authorities; the age to work in the sex industry will be raised to 21 years and clients have to check whether the sex worker is registered and not an undocumented worker. This article accounts for these two major shifts in prostitution policy in the Netherlands and discusses the consequences for sex workers.
\end{abstract}

Keywords Prostitution policy and law $\cdot$ Sex workers' rights

\section{Introduction}

In 1999, the Netherlands was one of the first countries to legalize prostitution; it lifted the ban on brothels, recognized prostitution as sex work and delegated the regulation of the

J. Outshoorn $(\bowtie)$

Institute of Political Science, University of Leiden, P.O Box 9555, 2300 RB Leiden, The Netherlands

e-mail: outshoorn@fsw.leidenuniv.nl sex industry to local authority (Outshoorn 2004a). Forced prostitution-including human trafficking-remained a criminal offence. People working in the sex industry were to become entitled to the social rights usually accruing to workers. Only EU citizens could work legally as prostitutes; those from the outside were not to receive work permits and thus become undocumented workers without rights and protection once their temporary visa expire. The new act took effect in 2000.

However, currently the Netherlands is reconsidering the act's reform; a new bill, the 'Law regulating prostitution and suppressing abuse in the sex industry' was introduced to parliament in 2009, with stricter measures to combat human trafficking and crime, but with more control of the sex industry and the sex workers. Sex workers, or prostitutes (the common term in Dutch public discourse), will be required to register with the authorities; the age to work in the sex industry is to be raised from 18 to 21 years, and clients will have to check whether the sex worker is registered and not an 'illegal' worker.

This article aims to provide insight into these two major changes in prostitution policy in the Netherlands by asking the following questions: How did the legalization come about in the Netherlands in 1999 and what was it intended to do? What led to its reconsideration in the 2000s? What are the aims of the new bill, and what consequences is it likely to have for sex workers? To answer these questions, I will examine the policy discourses frames of the major actors in the prostitution debates, set in the context of the history of the life cycle of the issue. From the reconstruction of the life cycle of the issue, the major actors were identified: cabinets, MPs, the Association of Dutch Municipalities, groups from the women's movement, the national police, experts (mainly academic researchers) and a number of journalists and current affairs writers. The sources of the 
texts with policy discourses are therefore diverse: the various policy papers and the bills produced by consecutive cabinets, the parliamentary records of the relevant debates, academic research on the 2000 enactment and the changes in prostitution in the Netherlands during the 2000s, as well as the most important literature produced by journalists and current affairs writers that played a role in the public debates of the period.

\section{The Road to Reform}

\section{The Long Road to Legalization}

In the nineteenth century, the Netherlands had a system of regulation of prostitution which allowed for brothels. Following a long abolitionist campaign of feminists and protestants, this regulation was repealed by the Morality Laws of 1911, which also criminalized abortion, contraceptives and homosexuality. Brothels were prohibited; pimps and others who lived off the earnings from prostitution were criminalized, but not the prostitutes, who were seen as women in need of redemption (De Vries 1997). The Morality Laws symbolized the new parliamentarian majority of the religious parties established in the early 1900s. However, the new abolitionist regime was never effective; in the course of the twentieth century, policy unofficially reverted to regulation when local authorities concentrated prostitution activities in certain areas and condoned 'private houses'. This was in line with the time-honored pragmatic approach of Dutch authorities to morally controversial issues in the absence of a moral consensus (Outshoorn 2004b). As long as public order was not threatened, authorities turned a blind eye to what was going on.

Although older discourses had generally portrayed prostitutes as victims of poverty or as 'fallen' or 'sinful' women, and in the 1950s and 1960s as 'psychiatrically disturbed', prostitutes were never criminalized under Dutch law. They were in possession of their civil rights (in contrast to countries where they were regarded as vagrants and lost their citizenship, such as the right to vote), and they were not excluded from the basic state benefits of social security and statutory old age pension.

Until the 1960s, the Morality Laws went unchallenged. Secularization and modernization then led to the breakdown of the system of Verzuiling (pillarization) that had organized Dutch society vertically along the cleavages of religion and class. The religious political parties lost their parliamentary majority in 1967. The opponents of the Morality Laws seized the opportunity for repeal, framing their claims in terms of undesirable state intervention in the private life of citizens. After intense and prolonged debate, contraceptives and abortion became legal and homosexuality and lesbianism were decriminalized. Only the ban on brothels and pimping remained on the books. This enabled the authorities to intervene if they led to the disruption of public order.

However, municipal authorities could not cope with the consequences of the development of the new globalizing sex industry in the late 1970s, which spread beyond the traditional red light districts of the major cities. There also were the first signs of women being trafficked from abroad. The Rotterdam city authorities tried to regulate prostitution, only to discover that their attempts were struck down by the courts, which argued that one cannot regulate what is forbidden by law. The issue made it to the parliamentary agenda when political parties wanted to modernize the penal code in the early 1980s and rid it of archaic elements such as work camps for pimps. Local authorities, united in the powerful Association of Dutch Municipalities (Vereniging van Nederlandse Gemeenten (VNG)) jumped at the opportunity to reform and demanded that the ban on brothels be lifted in order to regulate prostitution.

The demand for reform was strengthened by the strong feminist movement emerging in the late 1960s. In contrast to the feminist discourse in many other countries, Dutch feminists moved from a radical feminist discourse framing all prostitution as sexual violence to a pro-sex work position in the early 1980s, a framing familiar to them since the First World Whores Congress in Amsterdam in 1975. They distinguished 'forced' and 'voluntary' prostitution; only the latter was to be legalized, recognizing it as work. In alliance with feminists in government, they set three demands on the political agenda: lifting of the ban on brothels to improve the position of sex workers, residence permits for women who were trafficked so that they could testify against their traffickers and higher penalties for traffickers (Outshoorn 2004a: 186). Groups such as the Red Thread (Rode Draad) (1986), originally set up as a trade union of sex workers, and the Foundation against Trafficking of Women (Stichting tegen Vrouwenhandel (STV)) that aided victims of trafficking, were the prime movers of the feminist lobby.

The organization of the Red Thread was enabled by an old anti-abolitionist lobby (the Mr. de Graaf Foundation) and a small group of feminist activists who wanted to decriminalize prostitution (Verbeek 1996: 13-14). The Red Thread has been in favor of recognizing prostitution as work and prostitutes' rights and fighting the stigma of the 'whore'. Lifting the ban on brothels was seen as an important step towards achieving sex workers' rights. The STV started as a support group with outreach services for trafficked women but soon became a vocal lobby for victims of trafficking and expert on immigration issues. Using a feminist discourse stressing the agency of women, it always embraced the pro-sex work position and rejected the idea that legal prostitution would increase trafficking. Its major 
demands were to lift the ban on brothels and residence permits for trafficked women, achieved in 1988 when the first regulation allowing for this was adopted (known as the B 9 - Vreemdelingencirculaire since 2000). The Netherlands does not, however, allow humanitarian asylum for those migrant women who have been trafficked and testified against their traffickers.

The new sex work discourse resonated with the broader discursive field which developed in the wake of the 1960s about sexual freedom; it also drew on widespread liberal ideas about individual rights. In the new discourse, 'prostitution becomes a sexual service or sex work, a profession a woman can enter out of free will. The prostitute can dispense of her body for the purpose of prostitution by contract, in which case the state should not intervene' (Outshoorn 2001: 477). This resonance was a major factor in the policy change of 2000; liberals of various hues and the social democrats, who ascribed to the ideals of selfdetermination, could go along with sex work discourse. Between the feminist discourse and the market-oriented version of liberals, the major difference was the figure of the sex worker herself. For feminists, she was a person who needed rights to improve her position. Liberals used a gender-neutral market discourse which desexualized the people engaged in acts of prostitution (idem, 485). By treating both market parties as equal, they lost sight of the power relationships between the parties.

\section{The Parliamentary Debate}

Once on the political agenda, the road to reform proved rocky. The Christian parties in parliament might have lost their majority in 1967, but after merging into the Christian Democrat party (Christelijk Democratisch Akkoord (CDA)) in 1980, the successor party occupied the pivotal position in cabinet coalitions as the largest party, ruling either with the left or the right to make up a parliamentary majority. It could thus veto any reform on moral issues. Its traditional discourse framed prostitution as a moral and social evil, prostitutes as victims, and those profiting from her as unscrupulous middlemen. Although the CDA wanted a limited reform so that authorities could do their job, the sex work frame was morally unacceptable for them.

The secular parties, however, drawing on the discourse of self-determination, adopted the distinction between voluntary and forced prostitution and embraced the pro-sex work position. Consequently, there could be no cabinet consensus on the issue. When higher penalties for traffickers and more precise definitions of the offence were enacted in 1993, the CDA managed to torpedo the abolishment of the brothel ban by removing the proposed distinction between forced and voluntary prostitution from the draft bill (Outshoorn 2004a:
194, 195). The First Chamber subsequently voted down the amputated bill.

However, the political opportunities for the reformers improved hugely when the CDA was ousted from power in 1994 (the first time that religious parties were not a member of the ruling coalition since 1918). The Liberal Party (Volkspartij voor Vrijheid en Democratie), the Social Democrat Party (Partij van de Arbeid) and the Social Liberals (Democraten 66) formed the cabinet Kok I, the socalled Purple Cabinet. It drafted a new bill to lift the ban on brothels (HTK, 1996-1997, 25437, (Opheffing Algemeen Bordeelverbod), nos. 1-3, 1 July 1997). Parliament passed it in 1999; it came into effect in 2000 (Staatsblad 1999). Voting split neatly along the religious/secular divide. The sex work discourse was not hegemonic; the Christian parties (with $26 \%$ of the seats in the Second Chamber) stuck to their abolitionist position, and their traditional discourse had considerable support from the religious media and churchbased organizations. However, a poll in 1997 showed that $74 \%$ of the Dutch population regarded prostitution as work and $73 \%$ in favour of lifting the ban on brothels (Brants 1998: 628).

\section{Legal Changes}

\section{The New Prostitution Act}

The basic tenet of the new act was the distinction between voluntary and forced prostitution. Its aims were to control and regulate prostitution, to protect minors from sexual abuse (for which the age of consent, normally 16, was raised to 18 years) and 'protect' (not 'improve') the position of prostitutes (Staatsblad 1999). It also aimed at cleaning up the sex business and ridding it of criminal elements by introducing licensing of sex clubs and brothels. Forcing a person into prostitution remained a criminal offence, and force included the use of deceit, coercion or abuse of authority. There was considerable support from the local authority as the legalization was seen as a realistic solution for a social problem. It also fit into the progressive Dutch discourse about tolerance, an 'enlightened nationalism' which included respect for gay rights, permissive drugs policy, a liberal abortion regime, legal euthanasia and since 2001 same-sex marriage. Sex workers were to get additional rights: the right to do work of their own choosing, to social insurance and the recognition of their right to sexual selfdetermination. There were obligations too; they would have to pay taxes (if they were known to the revenue services, they were already taxed) and social security contributions.

The act delegated the implementation to the municipalities, so that they could tailor it to local circumstances. But they could not prohibit prostitution in their jurisdiction (the 
so-called zero option, popular among the religious parties) as this would contravene the new penal code articles. Local authorities have the responsibility to see to the licensing of sex businesses, but often they leave the inspection of under age prostitution and documents of migrant sex workers to the police. Many municipalities try to retain control by zoning, using environmental planning to prevent sex businesses in certain parts of town and limiting the number of licenses to those sex businesses already existing before 2000. Local health and safety/fire regulation also apply to sex clubs and brothels, and compliance is prerequisite to obtaining a license (Outshoorn 2004b).

\section{The Problem of Trafficking}

Trafficking arrived on the political agenda after pressure from feminists and the national women's policy agency. Originally, women were trafficked from Southeast Asia (notably Thailand and the Philippines), Latin America (Columbia and the Dominican Republic and Africa (Ghana); after the fall of the Berlin Wall, trade routes shifted to Central and Eastern Europe. Political demands were defining the offence more broadly to facilitate prosecution and raising the penalty from 5 to 6 years, so that offenders could be held in remand custody. The articles in the penal code on human trafficking were revised in 1993, with a more precise definition of the offence and higher penalties for traffickers (Outshoorn 2004a: 195). The articles were framed in a gender-neutral way, and trafficking remained defined as forcing a person into prostitution.

In the parliamentary debates on trafficking around that period, foreign women were portrayed as victims of unscrupulous traffickers tricked into prostitution. This framing was tied into a discourse about the divide between the rich and poor countries: female prostitutes from the 'Third World' were driven by poverty. Gradually, a more insidious edge crept into this discourse when Christian Democrats in parliament linked trafficking to illegal migration, opening a space for 'false' victims, who used the loopholes in the law to work illegally as a prostitute in the Netherlands (HTK, 1991-1992, TK 81, pp. 4994, 4995, 20 May 1992; p. 5001, 21 May 1992). At the same time they also started to argue that all women from non-EU countries working in the sex industry were victims of forced prostitution. Therefore in their view, the best remedy to stop trafficking was to prevent non-EU women from working in the Dutch sex industry in the first place. This reasoning eradicated the figure of a woman migrant deciding to work as a sex worker in the West and who might make use of intermediaries to enter the country-with her consent. But then she was 'illegal' and ought to be deported.

Successive cabinets continued to refuse work permits on similar grounds, also arguing there was no national interest at stake which normally justifies extending work permits to non-EU persons. They were backed by a recurring majority in parliament; the parliamentary records show many references to the fear of foreign prostitutes entering the country which would subvert immigration policies. The fear resurfaced in the memorandum to the bill to lift the brothel ban, as one of the aims of the bill was to halt 'the stream of foreign prostitutes' (HTK 1996-97, 25437 (Opheffing Algemeen Bordeelverbod), no. 3 (Memorie van Toelichting), 1 July 1997, p. 13). The refusal to grant work permits was also generally justified by the aim of stopping the trafficking of women; permits would encourage traffickers to transport women into the country.

\section{Categories of Sex Workers}

Subsequent implementation of the act resulted in the construction of no less than four categories of prostitutes. First of all, there is the ethnically undefined Dutch sex worker who willingly chooses to work in prostitution and is the bearer of civil and social rights. Secondly, there are the prostitutes from other EU countries who can move freely in and out of the Netherlands and work in the sex industry. This category split into two categories after the accession to the EU of the Baltic States, Poland, Hungary, the Czech Republic and Slovakia in 2004, making a third category who could only legally work as prostitutes if they were independent sex workers and not employees. This distinction did not apply to the Western European sex workers. In 2007, sex workers from the new EU members were accepted on an equal footing with the older EU member workers, but the third category was now filled with sex workers from Bulgaria and Romania when both countries joined the EU in that same year. Like their predecessors, these women are allowed to work as independent sex workers, but to date not as employees.

Fourthly, there is the category of non-EU women in the sex industry, working illegally with no rights, but they can be victims of trafficking or clients of human smugglers or tourists who stay after their visa run out - the enterprising migrants. They have no rights or protection, and because of their undocumented status, they are open to blackmail by employers and pimps.

The number of sex workers has always been open to debate. Vanwesenbeeck (1994) estimated that there were about 20,000 to 25,000 in the Netherlands and in parliamentary debates of the 1990s, the figure of 30,000 circulated. Asante and Schaapman (2005) estimated there were around 15,000-20,000, half of which are of foreign origin. In 2009, there were an estimated number of 5,150 to 7,660 sex workers in Amsterdam (Van Wijk et al. 2010: 9), but there are no recent reliable figures for the whole country. 


\section{The Outcomes of the Legalization}

\section{Early Reports}

The debate about the effects of the new act started almost straightaway, given the necessity of working out the details of the implementation. A first evaluation was already conducted in 2001-2002. The researchers of the Centre for Scientific Research and Documentation (WODC) of the Ministry of Justice, and their associates took care in pointing out that it was too early to say if the legalization was having a positive impact (Daalder 2002), but generally they were moderately optimistic. It emerged that local councils 'froze' the number of brothels in their precincts, not allowing new competitors to the market. Some orthodox protestant councils refused to license any sex business. Many prostitutes had little idea of their rights or duties, and attempts to reach them were inadequate. The licensing system was not yet in place in all municipalities, leading to displacement of criminalized prostitution such as under-age or undocumented prostitutes to tardy municipalities. Fieldwork in the nonlicensed sector noted instances of human trafficking and coercion, but the most frequent infringement of the law was the prostitute without a work permit, required by law for non-EU citizens (Goderie et al. 2002; Daalder 2002: 41). Daalder also reported a shift to non-regulated types of sex work, such as sauna's, (camper) cars and bars (idem, 44). Although the reports pay attention to countries of origin of the prostitutes, all reports are 'color blind'.

Looking specifically into the social position of prostitutes working in the licensed sector for the evaluation, Vanwesenbeeck et al. (2002) reported that sex workers had considerable autonomy but wondered if this finding was not due to socially desirable answers. If the women are independent workers, brothel owners do not have to deal with income tax or social insurance contributions for disability and unemployment. Given abundant evidence of control by managers (e.g. about dress, working hours and the percentage of the earnings going to the managers-indicative of the relation of employer over employee), the question arose how many of the women were really independent workers. Most sex workers and managers were in favour of work permits for non- EU workers.

The National Reporter on Human Trafficking produced a first annual report in 2002 (Mensenhandel 2002). It noted market shifts; there was not so much a displacement of prostitution from licensed brothels to street prostitution, as a burgeoning of escort services and services provided by sex workers in their homes. Both types of sex work were hard to tackle under the new licensing system. Rotterdam and Amsterdam also had notorious zones for street workers where organized and petty crime was rife and numerous signs indicated that many of the prostitutes working there were undocumented and sometimes victims of trafficking. These zones were closed in 2003 and 2004.

In the later reports of the National Reporter on Human Trafficking, there is a noticeable increase of the cases of trafficking. In 2001, 284 cases were reported, and in 2009, 909 (Mensenhandel 2010: 100). The higher figures are partly due the broader definition of the offence since 2005, when the incidence of forced labor in sectors such as horticulture and the restaurant business were included. The new article (237a penal code) also recoded forced prostitution as human trafficking, regardless of whether national borders had been crossed (Mensenhandel 2007). It is therefore not surprising that since 2005 the most frequent country of origin of victims of trafficking was the Netherlands itself, increasing to $39 \%$ of all cases in 2008 , with a slight decline to $26 \%$ in 2009) (Mensenhandel 2010: 101).

The research showed that the legalization led to the construction of two sectors of prostitution. Firstly, there was the licensed sector of prostitutes where under-age prostitutes, and undocumented workers were generally disappearing because of the licensing system and inspection by the police or local authority. Prostitutes working here were perceived to be white Dutch citizens, with other 'European' women making up the numbers. Secondly, there was the non-licensed sector, consisting of a variety of sex services, where pimping and coercion were still occurring and many prostitutes were 'illegal' or minors. The women working here were taken to be mainly 'foreign', coming from Eastern Europe and West Africa, who had taken the place of Latin American or Thai and Philippine women of earlier decades.

\section{The Public Debate}

Although the WODC evaluations were amply reported in the press, public indignation was first roused by several popular publications in the mid-2000s, which cast doubts on the official findings. First of all, a social democrat member of the Amsterdam City council, Karina Schaapman came out as an ex-prostitute by publishing a book about her past (Schaapman 2004). She made the case that most prostitutes do not choose to go into prostitution, but are more or less pressured into it because of drug addiction, debts or a past (sexual) abuse. With her colleague Amma Asante, she published a policy report for her party (Asante and Schaapman 2005) that denied the existence of voluntary prostitution (save for a very small group of sex workers) (idem, 3). Although they assured that they did not want to repeal the 2000 settlement, they explicitly declared it 'bankrupt'. The position of prostitutes had not improved, and many prostitutes had moved to 'invisible types' of prostitution, such as escort services and trafficking, violence and pimping were still widespread (idem, 5). The 
authors estimated that half of all prostitutes in the Netherlands were of 'foreign' descent (idem, 10) and driven to do the work by economic factors and therefore willing to work under bad conditions and for low wages. Exiting prostitution is difficult, as many have debts or do not speak Dutch. There is considerable drug abuse and many prostitutes have no health care insurance, while they run the risk of STDs and unwanted pregnancy. Asante and Schaapman's major recommendations were to license the escort services, criminalize pimping once more as traffickers of humans and raise the age of consent for sex work from 18 to 21 years. In 2007, Schaapman took up the issue of clients in another book (Schaapman 2007), framing the buying of sexual services as 'not normal' and casting further doubts about current policies. Her work set off the campaign of the leading social democrat alderman Asscher and his fellow party member Cohen, the mayor of Amsterdam, to clean up the Red Light district under the guise of fighting forced prostitution but also to gentrify the area and attract more upscale tourists (Asscher 2010; Weitzer 2012: 159-166). The Amsterdam party had direct access to the national government when the social democrats formed the new cabinet Balkenende IV with the CDA and the Christian Union in 2007. In its coalition pact, the new cabinet promised a new and stricter prostitution law (Regeerakkoord 2007).

Secondly, public concern was fuelled by a series of publications. Journalist Ruth Hopkins wrote her Ik laat je nooit meer gaan. Het meisje, de vrouw, de handelaar en de agent '('I will never let you go. The girl, the woman, the trafficker, and the police'), in 2005. It received widespread publicity, notably in the quality evening paper NRC Handelsblad that devoted a whole special to her findings (NRC Handelsblad, M bijlage, 7 November 2005). Her study is a strong indictment of how the authorities, notably the police, fail to deal with the trafficking of women. Although Hopkins is critical of the moralist view usually reserved for trafficking and of the estimates of the numbers of victims, her own construction of trafficking, focusing mainly on women from the Balkan, reproduces the classic narrative of how young women's hopes for a better life are fostered by ill-intending intermediaries who transport them over borders and coerce them to work in a brothel. This is ironic, as she accuses 'politics' of utilizing the simplistic story to strengthen 'Fortress Europe' and legitimate tough migration policies (idem, 2005: 242). Work permits for migrants who want to work in prostitution is, in her view, the best way of stopping trafficking of women, and it would dissolve the categories of the innocent victim and the guilty prostitute. A serious anthropological dissertation, based on extensive fieldwork among Latin American women who migrated to the Netherlands to work in the sex industry for economic reasons (Janssen 2007), received scant attention in the media.

Thirdly, there was the moral panic about 'loverboys'young men forcing vulnerable young girls into prostitution, giving rise to new welfare projects to 'save' them (Bovenkerk et al. 2006). The phenomenon led to much media attention, and a book by a victim (Mosterd 2008) sold more than 200,000 copies (it was later exposed as a fraud). The research of Bovenkerk et al., however, discovered few 'loverboys', but abundant evidence of regular pimping. In a deconstruction of the term, the researchers show how 'loverboys' are portrayed as young men, usually of Antillean or Moroccan descent, who set out to talk young white girls into prostitution. The researchers argue that pimping is no longer the preserve of white Dutch men who have moved on to more profitable criminal activities such as drugs trading. Pimping has become a niche for deprived young migrants for making a career in crime; the vulnerable white young girls are reminiscent of the scare of 'white slavery' of previous days. Bovenkerk et al. conclude that the aims of the 2000 enactment have not been met and that, given the omnipresence of pimping, there is little to suggest that prostitutes are working under improved conditions.

Finally, two researchers of the Red Thread, Altink and Bokerman (2006) did extensive fieldwork in licensed brothels but also irregular locations as Thai massage parlors, escort services and pick-up bars, to see if the working conditions of sex workers had improved. The Red Thread collected addresses of 633 of the estimated 800 sex businesses in operation; the researchers visited about half of those still in operation in 2005 (idem, 20). Their results show that proper working conditions are nearly non-existent and prostitutes still very dependent employees and hardly ever independent workers. Many have no legal residence, making them vulnerable to coercion and blackmail. The Red Thread still supported the legalization, but only under strict conditions, such as the upholding of labor law, proper monitoring by municipalities and stopping criminals from investing in the sex industry, and the right to bodily integrity. The Red Thread also investigated Thai massage parlors, often a cover for prostitution (Altink 2008). Despite its uncertain funding, the Red Thread has kept up lobbying parliament on the issue of the pending legal changes, notably on the point of the registration of sex workers and the criminalization of the client. However, it lost its ally STV, when the latter had to merge into a semi-state centre of expertise on human trafficking, CoMensha, thus losing its independence to lobby and its status as a part of the feminist movement. Feminist lawyers of the Association 
for Women and the Law Clara Wichmann have stepped in the protests by actively lobbying against the proposed Law regulating prostitution (Brief aan de Eerste Kamer, 11 April 2011).

\section{The Second Evaluation}

The second evaluation by the WODC took place in 20052006, and it concluded that the licensing system was now in place, regularly monitored, with little indication that the sex trade had moved to the non-licensed sector (Daalder 2007a: 11, 2007b). The researchers did not rule out that the market was shifting to the Internet or that the more traditional venues of prostitution, such as brothels, were in decline because of the weaker economy. Daalder concluded that some of the aims of the 2000 repeal had been achieved, such as the disappearance of under-age prostitutes and undocumented workers in the licensed part of the sex industry. At the same time, however, some of the reports on which she based her conclusions, showed that there was still much amiss (Dekker et al. 2006; Biesma et al. 2006). The rights of sex workers had not improved; forced prostitution and pimping were still recurring phenomena despite the fact that trafficking had become more difficult by improved law enforcement. Prostitutes had not become independent workers, although the majority of them maintained they were (Dekker et al. 2006: 82). This was to oblige the club owners and managers wanting to avoid the legal responsibilities of employers.

Pimping occurred in the escort services, in window prostitution and among women working from the home-all types of sex work in which it is easy to control womenand did not seem to have declined. A major loophole in the new regulations is that non-licensed sex clubs and escort services can easily move to municipalities where licensing requirements are non-existent or lenient, and the existence of shady businesses such as massage parlors, swing clubs and sauna clubs is hardly covered by local regulation. Dekker et al. concluded that, although prostitution had not become 'normal work', in the licensed sector, the quality of labor conditions was not 'structurally bad' despite the existing power relations on the job (idem, 80).

Biesma et al. (2006) noted a decline in legal prostitution facilities, but a growth of the non-licensed sector of escort agencies, sex clubs for couples and sex saunas. Street prostitution did not increase. They encountered some undocumented prostitutes from outside the European Economic Area, but little evidence of a larger underground illegal sector or any large contingent of minors working in the sex industry. The findings on trafficking concurred with those of the National Reporter of those years.

Although the research noted the countries of origin of prostitutes, making it possible to chart shifting patterns of migration, it did not comment on the racial or ethnic composition of the work force, nor did it question the categorization of sex workers resulting from the legalization. This most likely reflects the interests of the commissioning agent, the Ministry of Justice, and not the quality of the research, which is up to academic standards. It should be noted that none of the researchers, including independent academics such as Bovenkerk et al. (2006) and Wagenaar (2006), wanted to end the legalization, but have argued for better implementation of the existing rules and prioritizing the costs in the police budget. From the academic research, one can also draw the conclusion that not granting work permits to non-EU sex workers leaves them open to blackmail and coercion into poor working conditions and bad pay. In this way, policy actually creates the bad working conditions. Moreover, the emphasis on trafficking and vulnerable young victims has the effect of shifting the attention away from these conditions and the lack of prostitutes' social rights. Symptomatic is the scant attention these issues received in the recent parliamentary debates on the proposed Law regulating prostitution (see paragraph 5.b).

\section{The KLPD Report}

The strongest indictment of the situation came in 2008 when the investigative unit of the national police published a report on human trafficking during a widely publicized case of three Turkish traffickers who ran a major prostitution network in three cities, including Amsterdam (KLPD 2008) (Originally known as the Sneep case, it is now usually called the 'Saban B.' case after its prime mover). At least 78 women can be regarded as the victims of the gang (idem, 11). Notable was that the majority came from the Netherlands and Germany; the others were generally from EU countries such as Ireland, Bulgaria and the Czech Republic. The investigation reported many instances of severe violence against the women, including forced tattooing, coerced cosmetic surgery and even cases of forced abortion. The traffickers had operated quite openly in the licensed sector for several years, leading the researchers to investigate how this could have happened.

To analyze this question, the researchers examined the entire process from the first signals of forced prostitution, for instance by a prostitute in a contact with a social welfare or health care worker or a client, to local authority granting licenses and residence permits to workers, the police who take up a signal of trafficking and report to their superiors, and finally the public prosecution and the courts. The report shows how there are barriers to signaling abuse at each stage of the entire process. Intriguing is a tentative explanation provided by the KLPD team for the failure to signal coercion and force; any potential observer may be crosspressured by conflicting interests and turn a blind eye (idem, 
104-10). Prostitutes want the coercion to end but will not report from fear of deportation; clients might want to help but also want to have sex; club owners and managers' overriding concern is turnover, and they profit from low labor costs despite the risk of contravening regulations; social workers hesitate reporting, possibly jeopardizing their contact with the victim; local authorities work under pressure and want to avoid fuss; police, faced by performance measurement, are tempted to take up cases which are less time consuming and easier to prove; the public prosecutor worries whether the witnesses will turn up or the case holds in court and may abstain from prosecuting.

The KLPD report stressed that legalization had not ended abuse in the prostitution sector. Monitoring and regulation were no guarantee that women do not work under threat of coercion. According to the preface, 'the criminal investigation exudes threat, violence, fear and dependency. It is an illusion that a clean normal sector has emerged' (idem, 8). The evidence emerging from the Sneep case clashed with 'the dominant image of an almost cleansed prostitution branch' (idem, 10), an image the researchers ascribed to earlier police reports but also to the work of the WODC teams.

The KLPD report had two important effects. Firstly, it questioned the distinction between the licensed and nonlicensed sector, one supposedly clean and the other criminal. Secondly, it also overturned the distinction between the emancipated prostitute from the EU and the sorry victims from non-EU countries, as most of the trafficked women turned out to be EU citizens, notably from the Netherlands and Germany. The report received widespread publicity; later one of the KLPD team further fuelled public and parliamentary debate by publishing a book about his experiences in investigating forced prostitution (Werson 2012). Another recent publication by two journalists, although extending its scope to forced labor in general, draws extensively on the KLPD reports and comes out in favour of better implementation of existing regulation as well as supporting the higher age of consent for prostitution and controlling the escort services (Roessingh and Ramesar 2011).

Although there is no recent public opinion poll on attitudes towards prostitution and its regulation, the recurring media attention to all the reports, books, articles, events and incidents have in all likelihood led to a shift in public opinion about the regulation of prostitution in the 2000s.

\section{Political Reactions}

\section{Back to the Cabinet Agenda}

In the first years after the legalization, the Christian Democrat/Liberal/Social Liberal cabinet Balkenende II went along with the idea that it was too early to pronounce judgment on the new situation (e.g. TK 2002-2003, 25437, no. 30. Brief Minister van Justitie, 21 February 2003). However, the recurrent publicity about the persistence of trafficking of women and the 'loverboy' panic led to a renewed framing of sex workers as young girls as victims of abuse and trafficking as organized crime. This was picked up by christian democrats, orthodox protestants and the law-and-order liberals in parliament, who started to call for measures against 'youth prostitution' involving 'vulnerable young girls' or children. The definition of 'youth' or 'child' varied in parliamentary debate. The legal age for defining minors in the Netherlands is 18 , which is also the age of consent for sex work, while for sex in general it is 16 years. But in the new discourse, 'very young prostitutes' were all sex workers under 23 (TK 2002-2003, 25437, 25437, no. 31. Brief Minister, 13 May 2003, p. 12; (TK 2008-2009, 28638, no. 39. Verslag Algemeen Overleg Vaste Kamercommissie Justitie, 22 December 2008, p. 7; p. 13). At a later stage, christian and liberal MPs also came along with 'slightly mentally handicapped girls' in prostitution to lend further urgency to the issue (TK 2008-2009, 28638, no. 39, Verslag Algemeen Overleg Vaste Commissie Justitie, 22 December 2008, p.7; p. 11). No evidence, however, was found for this claim.

Given the publicity and parliamentary pressure, prostitution returned to the cabinet agenda in 2007, when the christian democrats, social democrats and christian unionists formed a new cabinet (Balkenende IV) and included the issue in their cabinet pact. Prostitution was framed as a 'breeding place' for crime, and penalties for both undocumented workers and clients, as well as setting up exit programs for women wanting to leave the trade, were proposed (Regeerakkoord 2007: 35).

This opened the debate on revising the 1999 act. The christian democrats began to argue that the romantic expectations about the lift of the ban on brothels in 2000 have led to nothing' (TK 2008-2009, 28638, no. 39, Verslag Algemeen Overleg Vaste Commissie Justitie, 22 December, p. 30) and demanded a higher age limit for sex work as well as more exit programs for prostitutes. The social democrats, although they rejected the youth framing by pointing out most prostitutes are adult women, went along with the victim discourse by stating that 'thousands' of women were a victim of coercion into prostitution (TK 2008-2009, 28638, Mensenhandel, no. 44, Verslag Algemeen Overleg Vaste Commissie Justitie, 13 July 2009, p. 2).

In the debates, the emphasis on youth prostitution and the link with organized crime shifted the spotlight from the older discourses which turned 'Third World' women into either victims of trafficking by definition or as calculating migrants entering the country illegally, to Eastern European victims (making the victim change color) while at the same 
time 'coloring' traffickers by emphasizing their Turkish or Balkan roots. Interestingly, the new articles on human trafficking in the penal code of 2005 (formulated to comply with the 2000 UN Protocol to Prevent, Suppress and Punish Trafficking in Persons) redefined forced prostitution as forced labor and no longer tie trafficking to the crossing of national borders. While the penal code now obliterates boundaries, nationalities, ethnicities and gender (it talks about 'persons'), many of the public and the politicians continue to see 'white girls and young women' and 'Balkan and Turkish gangsters'.

The New Bill 'Regulation of Prostitution and Suppression of Abuse in the Sex Industry'

The promised new bill was introduced in parliament in 2009 by the cabinet Balkenende IV (TK 2009-2010, 32211, Wet regulering prostitutie en bestrijding misstanden sex branche, 11 November 2009). It was adopted by the new minority liberal/christian democrat cabinet Rutte, with the support of the far right Freedom Party, when it came to power in 2010. The bill's major aim is to regulate prostitution in order to fight human trafficking, crime and abuse in the sex industry. To achieve this, it proposed a licensing regime of all forms of prostitution with uniform regulation across all communities (but keeping the option of a local ban open) and the registration of prostitutes. Licensing is also to apply to the escort services. The bill also proposed to raise the age for sex work to 21 years. If clients use the services of non-documented workers, they are liable to a fine, so as to make them 'personally responsible'. A more liberal regime to allow non-EU residents to work in the sex industry was opposed on the familiar grounds that it would make for more trafficking. The registration of prostitutes, with penalties for failing to do so-an unprecedented shift in Dutch prostitution policy - and several measures to clarify the difference between self-employment and wage work, were included to enable sex workers to work independently. Finally, the bill proposed extra measures for exit options for those who want to leave prostitution. In the words of the Liberal minister of justice: 'By the introduction of a compulsory licensing system in combination with compulsory registration and the national register of escort services, an almost closed administrative system is erected that can improve the fight against abuses in the sex industry and the judicial suppression of forced prostitution' (TK, 20102011, 51-8-60, Bestrijding misstanden sex branche, 10 February 2011).

Although both cabinets have made revisions of the text following committee debate, the major intentions were more or less unchanged by the time it was debated in plenary by the Second Chamber in spring 2011. There was consensus about the purposes of the bill among the parliamentary parties, none of which contested the dominant framing. The parties differed in their opinions about the 1999 act: the religious parties held it to be a failure, while the secular parties still supported the legalization and ascribed its shortcomings to failing law enforcement and loopholes in the original. Across the board many feared that the new bill would be the erection of a 'paper reality' of administrative measures which would prove to be ineffective.

The major bone of contention during the debates was the registration of the sex workers which aimed at preventing forced prostitution by establishing a contact between local authority and sex worker to check whether she was doing the work out of free will. But the registration is also about control; in the words of the minister for justice, 'Compulsory registration increases the visibility and the grip on the sex sector and retrieves prostitutes from anonymity' (idem, 51-8-59). All the secular parties objected to registration on the grounds of the right to privacy. Clients have to ask for the registration pass of their sex worker, otherwise they are also liable to prosecution. After opposing that the pass would disclose the sex worker's real identity to the client, the minister retracted the pass, but not the registration (TK, 2010-2011, 32211, no. 30, Derde Nota van Wijziging, 10 February 2011). This leaves open the question how a client is then supposed to check whether the sex worker was registered or not; an issue which has been left to later regulation.

The raising of the age of consent for sex work to 21 years was less controversial, although the left-wing parties and the Social Liberals had doubts about its effectiveness in curbing forced prostitution. The licensing of escort services and the harmonization of local regulation was generally supported, although there was debate whether municipalities could forbid prostitution outright (the 'zero option', amendment accepted) and whether home sex workers had to have a license like sex businesses (amendment not accepted) (EK 2010-2011, 32221 no. A, Gewijzigd voorstel van wet, 29 March 2011) The social rights of sex workers were only discussed at the last stage of the debates, during which the cabinet promised to take away the obstacles to their right to work. It also promised to extend exit programs for prostitutes, a favorite of the religious parties, but also supported by the social democrats.

Despite the reservations of the secular parties, only the Green Left party and the Social Liberals voted against the bill, so that it received a generous majority (TK, 2010-2011, 26 March 2011). Noteworthy is the shift in position of the Socialist and the Social Democrat party, who had both voted in favor of lifting the ban on brothels in 1999, but now went along with the new framing. The newcomer Freedom Party, who originally tabled raising the age of consent for sex work, sided with the religious parties; its discourse about victims, vulnerable young girls, the prevalence of 
'loverboys' and lusting clients is little different from that of the Orthodox Christian parties.

The bill has received its first reading in the First Chamber, where most parties were highly critical, doubting whether the bill will actually achieve its aims and if the proposed registration does not contravene the right to privacy (EK 2011-2012, 32211, D, Nader Voorlopig Verslag, 13 December 2011). The minister of justice still has to respond to the critique before it can be taken to the final vote. Complicating the issue is that the cabinet Rutte has only 37 of the 75 seats in the chamber, making it dependent on the opposition to pass the bill. The First Chamber does not have the right to amend bills and must therefore either pass or fail the bill in its entirety. It remains to be seen whether the First Chamber, a house of review traditionally strong on constitutional rights and legal technical issues, will find enough justification to fail it.

\section{Conclusions}

The Netherlands legalized prostitution in 1999 as the old articles in the penal code, which forbade brothels and profiting from the gains of prostitution (but did not criminalize the prostitute), no longer sufficed to control the globalizing sex industry in the last decades of the twentieth century. Local authority could not curb the excesses, as the courts struck down any attempt at regulation as contravening the penal code. The national association of the municipalities (the VNG) demanded the lift of the ban on brothels, so that local authority could regulate the sex industry, a demand picked up by parliament in the early 1980 s. The new feminist movement developed the new framing of prostitution as work and the prostitute as a modern and emancipated sex worker. This proved compatible with the liberal discourse on the issue, favouring individual choice and treating the sex business as a normal business, and with the feminism of the Left. In this way, it became the dominant discourse among the secular parties. When the Christian Democrats - opposed to legalizing prostitution - were ousted from power in 1994, the secular Purple cabinets (1994-2002) seized the opportunity to legalize prostitution, with a view to regulating in a pragmatic way. In 1999, the new act was passed, with the voting neatly split along the secular/religious cleavage in parliament. Implementation of the new act was delegated to local authority, responsible for health and safety requirements, and sex workers became eligible for social rights as well as for paying taxes and social insurance.

However, consecutive evaluations of the new act in the 2000s showed that the new system did not solve a number of serious problems in the sex industry. Although there was now a licensed sector where few minors or undocumented workers worked, there was considerable displacement to the footloose escort service branch and evidence that abuse of sex workers and human trafficking was still around. The Sneep case showed that even in the licensed sector forced prostitution occurred and that its victims were mainly Dutch and EU women and not the stereotypical poor girls from Eastern Europe. The 'numbers' question is unsolved and remains contentious in public debate.

Important also in changing public opinion has been the widespread publicity on the trafficking of women in the popular media and the 'loverboy' panic, leading to a renewed discourse about young female victims which eclipsed the image of the modern consenting sex worker. Opponents of the legalization at first found willing ears in parliament among the religious parties. Window of opportunity was the coming to power of new cabinet Balkenende IV in 2007, when all three coalition partners ascribed to a new framing of the issue as the trafficking of (young) women and the need to fight organized crime. The fear of illegal migration played a role in revising the law but so did the continual publicity about forced prostitution and its victims. The new framing is compatible with the policy discourse of the current right wing government about lawand-order and migration, as signified by its adoption of the bill of the preceding cabinet. The proposed law, with its intricate system of licensing, registration of prostitutes and criminalization of the client if he uses the services of a nonregistered sex worker, has been passed by the Second Chamber in 2011. It is uncertain if the First Chamber will accept the bill.

For the rights of sex workers, the legal changes do not augur well. The bill does little to remedy the lack of social rights, and the stigma of sex work remains intact, so that many sex workers prefer to remain anonymous. The proposed registration of prostitutes and the new age barrier to work are new infringements of their civic and social rights. The right to work is 16 years in the Netherlands, and registration with the (local) state is an obligation which goes beyond the customary registration of businesses and professionals at the chamber of commerce for tax purposes. The registration is a real danger to their right to privacy, more so, as the Dutch state has a bad record in safeguarding the privacy rights of its citizens (Kagie 2010). Undocumented workers remain open to blackmail because of their illegal status. The new legislation will make it harder for them to find work, as the client will run a risk using their services. The cabinet will not extend humanitarian asylum status to trafficked women or grant work permits to non-EU prostitutes. The categories of sex workers created in 2000 will therefore stay intact, although the occupants of the categories have different nationalities and ethnicities than in the 1990s, a consequence of the enlargement of the EU. It has to be concluded that the state, by its slack implementation of the 2000 act and lack of attention to social rights in the 
proposed bill, is responsible for creating the bad working conditions, intimidation and blackmail itself.

Open Access This article is distributed under the terms of the Creative Commons Attribution License which permits any use, distribution, and reproduction in any medium, provided the original author(s) and the source are credited.

\section{References}

Altink, S. (2008). Een vergeten groep of Thaise vrouwen in (erotische) salons in Nederland. Amsterdam: De Rode Draad.

Altink, S., \& Bokelman, S. (2006). Rechten van prostituees. Evaluatie Opheffing Bordeelverbod. De sociale positie van prostituees. Amsterdam: De Rode Draad.

Asante, A., \& Schaapman, K. (2005). Het onzichtbare zichtbaar gemaakt. Prostitutie in Amsterdam. Amsterdam 2005. Nota Partij van de Arbeid.

Asscher, L. (2010). De Ontsluierde Stad. Amsterdam: Bert Bakker.

Biesma, S., Van der Stoep, R., Naayer, H., \& Bieleman, B. (2006). Verboden bordelen. Evaualtie Opheffing bordeelverbod nietlegale prostitutie. Groningen: Intraval.

Bovenkerk, F., San, M., Boone, M., Boekhout van Solinge, T., \& Korf, D. (2006). Loverboys of modern pooierschap. Amsterdam: Augustus.

Brants, C. (1998). The fine art of regulated tolerance: prostitution in Amsterdam. Journal of Law and Society, 25, 621-635.

Daalder, A. L. (2002). Het bordeelverbod opgeheven: prostitutie in 2000-2001. Den Haag: WODC.

Daalder, A. L. (2007a). Prostitutie in Nederland na opheffing van het bordeelverbod. Den Haag: WODC. Onderzoek en Beleid, nr. 249.

Daalder, A. L. (2007b). De opheffing van het bordeelverbod. Gevolgen voor mensenhandel? Justitiële Verkenningen, 33(7), 64-77.

Dekker, H., Tap, R., \& Homburg, G. (2006). De sociale positie van prostituees. Eindrapport. Amsterdam: Regioplan.

Goderie, M., Ter Woerds, S., \& Spierings, F. (2002). Illegaliteit, onvrijwilligheid en minderjarigheid in de prostitutie een jaar na de opheffing van het bordeelverbod. Utrecht: Verwey-Jonker Instituut.

Hopkins, R. (2005). Ik laat je nooit meer los. Het meisje, de vrouw, de handelaar en de agent. De Geus: Breda.

Janssen, M.-L. (2007). Reizende Sekswerkers. Latijns-Amerikaanse vrouwen in de Europese prostitutie. Amsterdam: Het Spinhuis ( $\mathrm{PhD}$ dissertation, University of Amsterdam).

Kagie, R. (2010). Privacy. Hoe Nederland verandert in een controlestaat. Amsterdam: Uitgeverij Contact.
KLPD (2008). Schone schijn. De signalering van mensenhandel in de vergunde prostitutiesector (report Dienst Nationale Recherche KLPD -Central Investigation Unit, National Police Force).

Mensenhandel. (2002). Eerste rapportage van de Nationaal Rapporteur. Den Haag: Bureau NRM.

Mensenhandel. (2007). Vijfde rapportage van de Nationaal Rapporteur. Den Haag: Bureau NRM.

Mensenhandel. (2010). Tien jaar NRM. Den Haag: Bureau NRM.

Mosterd, M. (2008). Echte mannen eten geen kaas. Amsterdam: Van Gennep.

Outshoorn, J. (2001). Debating prostitution in parliament. A feminist analysis. European Journal of Women's Studies, 8(4), 47291.

Outshoorn, J. (2004a). Voluntary and forced prostitution: the 'realistic approach' of the Netherlands. In J. Outshoorn (Ed.), The politics of prostitution. Women's movements, democratic states and the globalization of sex commerce (pp. 185-205). Cambridge: Cambridge University Press.

Outshoorn, J. (2004b). Pragmatism in the Polder: changing prostitution policy in the Netherlands. Journal of Contemporary European Studies, 12(2), 165-177.

Regeerakkoord (2007). Coalitieakkoord tussen de Tweede Kamerfracties van CDA PvdA en ChristenUnie. 7 februari 2007.

Roessingh, M., \& Ramesar, P. (2011). Slaven in de polder. Hoe sekswerkers, schoonmakers en seizoenarbeiders worden uitgebuit. Amsterdam: Uitgeverij Atlas.

Schaapman, K. (2004). Zonder moeder. Amsterdam: Balans.

Schaapman, K. (2007). Hoerenlopen is niet normaal. Twijfels bij een liberaal prostitutiebeleid. Amsterdam: Balans.

Staatsblad (1999) Opheffing bordeelverbod.

Vanwesenbeeck, I. (1994). Prostitutes' well-being and risk. Amsterdam: Free University Press.

Vanwesenbeeck, I., Höing, M., \& Vennix, P. (2002). De sociale positie van prostituees in de gereguleerde bedrijven, een jaar na wetswijziging. Utrecht: Rutgers Nisso Groep/WODC, Ministerie van Justitie.

Verbeek, H. (1996). Goede bedoelingen. Zaakwaarnemrs in een hoerenorganisatie. Amsterdam: Het Spinhuis.

de Vries, P. (1997). Kuisheid voor mannen. Vrijheid voor vrouwen. De reglementering en bestrijding van prostitutie in Nederland, 1850 1911. Verloren: Hilversum.

Wagenaar, H. (2006). Democracy and prostitution: deliberating the legalization of brothels in The Netherlands. Administration and Society, 38(3), 198-235.

Weitzer, R. (2012). Legalizing prostitution. From illicit vice to lawful business. New York: New York University Press.

Werson, H. (2012). De fatale fuik. Amersfoort: TM Publishers.

van Wijk, A., Nieuwenhuis, A., van Tuyn, D., van Ham, T., Kuppens, J., \& Ferwerda, H. (2010). Kwetsbaar beroep. Een onderzoek naar de prostitutiebranche in Amsterdam. Amsterdam: Bureau Beke. 